\title{
В.В. Шовківська,
} аспірантка

ORCID: 0000-0002-2379-0362

Київський національний університет будівництва і архітектури

\section{ІННОВАЦІЙНИЙ РОЗВИТОК ЛЮДСБКОГО КАПІТАЛУ ЯК ВАЖЛИВИЙ ЧИННИК ЕКОНОМІЧНОГО ЗРОСТАННЯ БУДІВЕЛЬНОЇ ГАЛУЗІ}

В Украӥні за відносно значних обсягів інвестування у людський капітал ефективність інвестииій залишається порівняно невисокою, тому актуалізується проблема нарощчення інноваційного людського капіталу за допомогою підвищення ефективності вкладення коштів $i$ підвищення ефективності роботи суспільних інститутів, відповідальних за його формування $i$ розвиток, щзо $\epsilon$ першоосновою економічного зростання та конкурентоспроможності будівельної галузі.

Метою статті є проведення аналітичних досліджень прочесу інвестування $в$ інноваційний розвиток людського капіталу та зарубіжного досвіду інвестування в розвиток людського капіталу.

Визначено, щуо інвестиції в інноваційний розвиток людського капіталу значною мірою залежать від видатків зведеного бюджету України на сочіально-культурні заходи та освіту, які протягом останніх років суттєво зменшились (на освіту - $з$ 19,1\% в 2014 до 16,8\% в 2018 р., на охорону здоров'я - з 10,9\% в 2014 р. до 9,3\% в 2018 p., на соиіальний захист - на 1,7\%). Недостатне фінансування з боку держави видатків на освіту, охорону здоров'я, духовний та фізичний розвиток стримувало впродовж останніх років розвиток інновачійного людського капіталу, економічне зростання та підвищення конкурентоспроможності будівельної галузі.

У статті розкривається вплив інноваційного розвитку людського капіталу на економічне зростання будівельної галузі. Значну увагу приділено інвестування в інноваційний розвиток людського капіталу Украӥни $і$ прогресивному зарубіжного досвіду вирішення даної проблем. Відзначається, щчо орієнтація украӥнської економіки та будівельної галузі зокрема на формування та розвиток інноваційного людського капіталу має забезпечуватися комплексним заходами, що реалізуються центральними і територіальними органами державної влади, органами управління будівельної галузі, роботодавців і представників сфери освіти та науки, державної служби зайнятості, а також шляхом поглиблення взаємодї з СС, в рамках існуючих програм партнерства з європейськими краӥнами в частині інноваційного розвитку людського капіталу.

Ключові слова: людський капітал, будівельна галузь, інноваційний розвиток, інвестування в розвиток людського капіталу.

Вступ. Перспективи економічного розвитку національної економіки в сучасних умовах в значній мірі залежать він інноваційного розвитку людського капіталу. У XXI столітті людський капітал $€$ загальновизнаним активом економічного зростання та джерелом соціального розвитку. Набувають актуальності питання залучення й ефективного використання ресурсів для нарощення продуктивних здібностей осіб 3 максимальною користю для інвесторів - людини, підприємства, країни. В Україні за відносно значних обсягів інвестування у людський капітал ефективність інвестицій 
залишається порівняно невисокою. 3 огляду на це актуалізується проблема нарощення інноваційного людського капіталу за допомогою підвищення ефективності вкладення коштів і підвищення ефективності роботи суспільних інститутів, відповідальних за його формування i розвиток, що $\epsilon$ першоосновою економічного зростання та конкурентоспроможності будівельної галузі.

Аналіз досліджень i публікацій. Дослідженню процесу формування використання і розвитку людського капіталу приділена значна увагу. Це знайшло відображення у працях О.А. Грішнової, В.М. Лича, Н.В. Ушенко, Т.М. Кір'ян, І.К. Бондар, А.М. Колота, Л.І. Антошкіної та інших.

Постановка завдання. Провести аналітичні дослідження процесу інвестування в інноваційний розвиток людського капіталу та зарубіжного досвіду інвестування в розвиток людського капіталу.

Основна частина. У сучасному світі економічне зростання завдячує інноваціями, які тісно пов'язані з розвитком людського капіталу. У суспільстві знань підвищується роль творців нового, а також інноваційних відносин, мереж, технологій тощо. Науково-технічний прогрес, інтелектуалізація праці цілком спричинені розвитком людських якостей $\mathrm{i}$ здібностей шляхом поширення та поглиблення освіти, нагромадження знань.

У XXI столітті людський капітал $є$ загальновизнаним активом інноваційного розвитку та економічного зростання. Набувають актуальності питання залучення й ефективного використання ресурсів для нарощування продуктивних здібностей осіб $з$ метою розвитку людського капіталу, спрямованого на інноваційні зміни розвитку економіки держави. Вирішення проблем розвитку людського капіталу на інноваційній основі сприятиме досягненню не лише короткострокового економічного успіху, а й в закладе основу формування позитивних довготермінових тенденцій у розвитку усіх видів економічної діяльності, в тому числі і будівельної галузі. Інтелектуалізація виробництва і праці, потреби інноваційного розвитку будівельної галузі висувають до працівників нові дедалі більші вимоги - і в професійному, і в особистісному зростанні, в творчому ставленні до роботи, тобто ставиться питання щодо інноваційного розвитку людського капіталу.

Передумовою ефективного впровадження інновацій в будівельний процес $є$ достатньо розвинута інноваційна інфраструктура, під якою мається на увазі інтегрована в єдину систему сукупність взаємопов'язаних економічних підсистем (інформаційного забезпечення, експертизи, якості, фінансово-економічного забезпечення, матеріально-виробничої, кадрової тощо), які комплексно сприяють забезпеченню оперативного та ефективного функціонування інноваційних процесів.

Усі підсистеми інноваційної інфраструктури тісно пов'язані між собою і від їх взаємодії залежить впровадження інновацій у виробництво та подальше використання інноваційної продукції для економічного зростання та підвищення конкурентоспроможності будівельної галузі.

Зростаюча роль людського капіталу в економічному зростанні обумовлена інвестуванням в його розвиток у зв'язку із подальшим впровадженням новітніх технологій, що вимагає високоосвічених працівників у виробничій сфері.

Інвестиції в інноваційний розвиток людського капіталу значною мірою залежать від видатків зведеного бюджету України на соціально-культурні заходи та освіту як важливих чинників розвитку людського капіталу (табл.1).

Так видатки на освіту в загальній сумі видатків Зведеного бюджету знизились 3 
19,1\% в 2014 до 16,8\% в 2018 р., тобто знизились на 2,3 відсоткових пункти. Особливо неефективно розвивалась професійно-технічна освіта - видатки скоротились $31,1 \%$ в 2014 до 0,8\% в 2017 р. Видатки зведеного бюджету на охорону здоров'я зменшились 3 10,9\% в 2014 р. до 9,3\% в 2018 р., тобто зменшились на 1,6 відсоткових пункти; видатки на духовний та фізичний розвиток зменшились відповідно на 0,3 відсоткових пункти; видатки на соціальний захист зменшились на 1,7 відсоткових пункти.

Таким чином, недостатнє фінансування з боку держави видатків на освіту, охорону здоров'я, духовний та фізичний розвиток стримувало впродовж останніх років розвиток інноваційного людського капіталу, економічне зростання та підвищення конкурентоспроможності будівельної галузі.

Таблиия 1

\section{Видатки Зведеного бюджету на соціально-культурні заходи та освіту за період 2014-2018 рр.}

(у відсотках до загальної суми видатків Зведеного бюджету)

\begin{tabular}{|c|c|c|c|c|c|c|}
\hline & 2014 & 2015 & 2016 & 2017 & 2018 & $\begin{array}{c}2018 / \\
2014, \\
\%\end{array}$ \\
\hline Освіта & 19,1 & 16,8 & 15,5 & 16,8 & 16,8 & $-2,3$ в.П. \\
\hline \multicolumn{7}{|l|}{3 них } \\
\hline дошкільні освіта & 2,9 & 2,7 & 2,4 & 2,7 & & \\
\hline загальна середня освіта & 8,1 & 7,3 & 6,8 & 8,0 & & \\
\hline $\begin{array}{l}\text { професійно-технічна } \\
\text { освіта }\end{array}$ & 1,1 & 0,9 & 0,7 & 0,8 & & \\
\hline вища освіта & 5,4 & 4,6 & 4,2 & 3,7 & & \\
\hline Охорона здоров'я & 10,9 & 10,4 & 9,0 & 9,7 & 9,3 & -1,6 в.П. \\
\hline $\begin{array}{l}\text { Духовний та фізичний } \\
\text { розвиток }\end{array}$ & 2,6 & 2,4 & 2,0 & 2,3 & 2,3 & $-0,3$ в.п. \\
\hline \multicolumn{7}{|l|}{ 3 них } \\
\hline культура та мистецтво & 1,6 & 1,3 & 1,3 & 1,5 & & \\
\hline $\begin{array}{ll}\text { засоби } & \text { масової } \\
\text { інформації }\end{array}$ & 0,2 & 0,2 & 0,2 & 0,2 & & \\
\hline $\begin{array}{lll}\text { фізична } \\
\text { спорт }\end{array}$ & 0,8 & 0,9 & 0,5 & 0,7 & & \\
\hline $\begin{array}{l}\text { Соціальний захист та } \\
\text { соціальне забезпечення }\end{array}$ & 26,4 & 25,9 & 30,9 & 27,0 & 24,7 & -1,7 в.п. \\
\hline
\end{tabular}

Враховано дані бюджетної звітності за І квартал 2014 року по Автономній Республіці Крим та м. Севастополь. (Джерело: складено за даними [1, C. 17])

Слід відмітити, що будівельний комплекс - один із найбільш важливих секторів національної економіки, що забезпечує функціонування багатьох інших галузей, створює умови для розвитку інших галузей, реалізації інноваційних проектів, залучення інвестиційних ресурсів. Проте, на сучасному етапі економічних перетворень процес розвитку людського капіталу підприємств будівельної галузі стимулюється недосконалістю підготовки робітників і фахівців у професійно-кваліфікаційному розрізі, неналежним фінансуванням освітніх 
закладів, неефективністю інвестиційної політики, бюджетного фінансування таких важливих чинників розвитку людського капіталу як освіта, охорона здоров'я, духовний та фізичний розвиток тощо.

Проблема недофінансування інвестицій в розвиток людського капіталу загострюється в умовах, коли підприємства будівельної галузі обирають тактику скорочення собівартості на основі економії на заробітній платі та недофінансування соціальних витрат.

Пріоритетними напрямами діяльності підприємств будівельної галузі щодо розвитку людського капіталу повинно стати системне бачення процесу розвитку людського капіталу на базі зниження собівартості будівельної продукції, забезпечення ефективної роботи із замовниками, розширення інвестиційного портфелю, будівництва соціально-орієнтованого житла, проведення активної інформаційної політики щодо зростання корпоративної репутації будівельних підприємств й розвитку людського капіталу, застосування сучасних технологій i матеріалів, технічних та комунікаційних засобів, інформаційних баз даних, тощо.

Процес розвитку людського капіталу підприємств будівельної галузі потрібно удосконалювати шляхом реформування відносин центральних й територіальних органів управління будівельної галузі, професійних закладів освіти, роботодавців, державної служби зайнятості.

Державним центральним й територіальним органам управління будівельної галузі необхідно: обгрунтувати й сформувати ідеологію розвитку людського капіталу, пов'язаної із теорією гідної праці і якості трудового життя в будівельній галузі; розробити й реалізувати Концепцію розвитку людського капіталу на базі інвестицій на навчання, підвищення кваліфікації, оздоровлення й інші аспекти 3 врахуванням специфіки роботи будівельної галузі; здійснювати систематичне прогнозування потреби будівельної галузі в робітниках і фахівцях за професійнокваліфікаційним складом; сформувати ефективну систему підготовки й перепідготовки кадрів будівельної галузі.

Слід наголосити, що інвестиції в інноваційний розвиток людського капіталу пов'язані з положенням та роллю в суспільстві середнього класу, представники якого становлять до 60-80\% зайнятого населення в розвинутих країнах світу. Для цих осіб характерні високі рівні доходів, висока якість життя, в тому числі висока якість трудового життя, високий професіоналізм, високий рівень освіти та культури, самозабезпечення висококваліфікованою працею, розвинута трудова етика і переважно нематеріальна трудова мотивація.

Враховуючи офіційний низький рівень доходів значної частини населення, наявність населення, що працює в тіньовому секторі або отримує з нього доходи, вважаємо за можливе стверджувати, що інвестиції в інноваційний розвиток людського капіталу, формування і розвиток середнього класу в Україні можливо на основі гідної праці - продуктивної праці в умовах свободи, рівності, безпеки та поваги до людської гідності [2, С. 12-13].

Гідна праця, по-перше, забезпечує: справедливу заробітну плату, безпеку на робочому місці; соціальний захист найманих працівників та членів їх родин; соціальну інтеграцію; по-друге, сприяє особистому розвитку; по-третє, дає можливість вільно висловлювати свою думку та об'єднуватися з метою впливу на рішення стосовно життя людини; по-четверте, гарантує рівні можливості для усіх членів суспільства (рис. 1). 


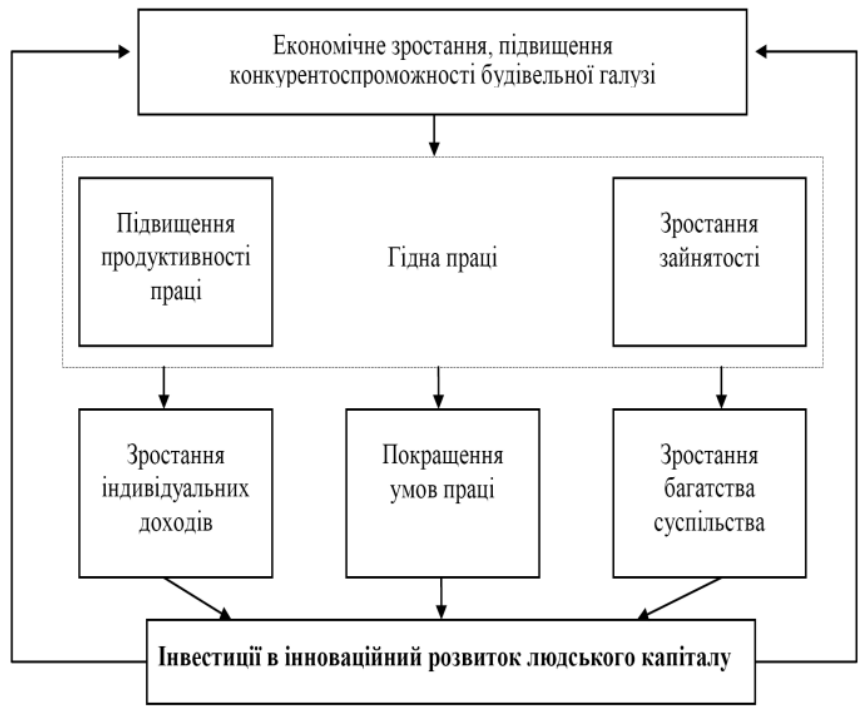

Рис. 1. Взаємозв'язок інвестування в інноваційний розвиток людського капіталу та економічним зростанням і конкурентоспроможністю будівельної галузі (Джерело: розроблено автором)

Кінцевою метою інвестицій в інноваційний розвиток людського капіталу $е$ підвищення якості життя населення на базі гідної праці працівників усіх видів економічної діяльності, в тому числі будівельної галузі.

Зв'язок інвестування в інноваційний розвиток людського капіталу в контексті підвищення якості життя населення зумовлюється декількома причинами:

- якість трудового життя - це узагальнення, що характеризує умови використання людського капіталу і трудового потенціалу. Саме трудовий потенціал i людський капітал як його активна, задіяна частина в наш час стають визначальними чинниками соціально-економічного розвитку. Отож їх розвиток за рахунок інвестицій та умови їх використання, що характеризуються якістю трудового життя, значною мірою визначають ефективність як виробництва, так i соціального прогресу;

оскільки більша частина свідомого життя дорослих людей проходить на робочому місці, висока якість трудового життя стає вирішальною складовою якості життя громадян загалом;

- висока якість трудового життя $\epsilon$ важливим чинником піднесення ефективності роботи підприємств будівельної галузі, оскільки позитивно впливає на організацію праці, іiі продуктивність, на якість робочої сили, на корпоративну культуру і мотивацію праці та професійного розвитку;

якість трудового життя $є$ результатом і показником стану та міри 
розвинутості соціально-трудових відносин, виступає цільовим орієнтиром у проведенні соціального діалогу з приводу забезпечення сприятливих умов трудової діяльності.

Таким чином, інвестування в інноваційний розвиток людського капіталу будівельної галузі тісно пов'язане із ідеологією гідної праці та якістю трудового життя працюючих із інноваційним людським капіталом на підвідомчих підприємствах галузі. Щоб залучити, втримати і розвивати таких працівників, підприємство має створити умови для задоволення їхніх потреб - щодо інтелектуальної, творчої, соціальної реалізації в процесі роботи, інноваційної спрямованості трудової діяльності. А це і $є$ основні складові високої якості трудового життя.

Слід відмітити, що інноваційний людський капітал, тобто працівники 3 вищими якісними характеристиками (високим рівнем освіти, професійних навиків, мотивації, мобільності і здоров'я) мають більш високі заробітки та забезпечують зростання доходів населення, що веде як до збільшення сукупного попиту, так і до збільшення заощаджень, які стають джерелом інвестицій. Інвестиції в інноваційний розвиток людського капіталу позитивно впливають на рівень конкурентоспроможності як робочої сили, так і виробництва в цілому і будівельної галузі зокрема. Високий рівень людського капіталу та його розвиток забезпечують можливість руху країни до наукоємної високотехнологічної та інноваційної економіки.

Необхідно зазначити, що інноваційний розвиток економіки в значній мірі залежить від фінансування внутрішніх витрат на виконання наукових досліджень і розробок. За попередніми розрахунками, питома вага загального обсягу витрат у ВВП у 2017 р. становила $0,45 \%$, в тому числі за рахунок коштів державного бюджету 0,16\% [3, С. 56]. За даними 2016 р., частка обсягу витрат на НДР у ВВП країн СС-28 у середньому становила 2,03\%. Більшою за середню частка витрат на дослідження та розробки була у Швеції - 3,25\% Австрії - 3,09\%, Німеччині - 2,94\%, Данії-2,87\%, Фінляндії-2,75\%, Бельгії-2,49\%, Франції-2,25\%.

Витрати на НДР в країнах СС - це масштабні програми, що безпосередньо стосуються соціально-економічного та інноваційного розвитку суспільства. Серед таких програм можна назвати: «Європа 2020» стратегія соціально-економічного розвитку Свропейського Союзу на період до 2020 р., прийнята Свропейською радою навесні 2010 р. [4].

Для досягнення поставлених цілей стратегії в якості пріоритетних висунуті наступні напрямки діяльності:

«Інноваційний Союз» - об’ єднання зусиль для створення і впровадження інновацій, що дозволить використовувати інноваційні ідеї у виробництві товарів і послуг. Це сприятиме створенню нових робочих місць і зростання економіки. Для досягнення даної мети 3\% ВВП ЄС має бути інвестовано в дослідження і розробки;

людей на ринок праці; «Рух Молоді» - стосується підвищення якості освіти, залучення молодих «Розвиток цифрових технологій в Європі» - спрямований на розширення використання високошвидкісного Інтернету і надання можливостей участі фізичних і юридичних осіб в загальному цифровому комерційному просторі [5];

- «Раціональне використання ресурсів в Свропі» - спрямований на розумне використання джерел енергії, збільшення використання джерел відновлюваної енергіi; 
«Індустріальна політика, спрямована на глобалізацію» передбачає поліпшення умов для підприємництва, в першу чергу для малого і середнього бізнесу, розвиток потужної і стійкої промислової бази для адаптації економік до глобалізації;

«План 3 розвитку нових здібностей і збільшення кількості робочих місць» пов'язаний 3 підвищенням мобільності трудових ресурсів, наданням можливостей для отримання нових знань і навичок, щоб збільшити можливості для працевлаштування.

«Європейська політика проти бідності» - спрямована на зниження рівня бідності в ЄС за рахунок розширення взаємодії на всій території Європейського Союзу за рахунок економічного розвитку та підвищення зайнятості» [6].

Для того, щоб держави-члени змогли адаптувати стратегію «Свропа 2020» до своєї конкретної ситуації, Європейська Комісія пропонує державам трансформувати цілі ЄС в свої національні стратегії.

В рамках даної стратегії існує ініціатива «Свропа 2020», яка спрямована на підвищення рівня якості і доступності навчання у навчальних закладах усіх рівнів. Значна увага приділяється створенню умов для студентів навчатися за кордоном та отриманню універсальних і актуальних для сучасного розвитку суспільства вмінь i навичок, які надавали б їм можливості успішного працевлаштування в усіх країнах світу [6].

Особливу увагу в реалізації даної ініціативи заслуговує такий інструмент іiі реалізації як «Освіта і підготовка 2020» - концепція навчання протягом усього життя (lifelong yearning). Дана концепція спрямована на всебічну навчальну діяльність, здійснювану на постійній основі, з метою поліпшення знань, навичок і професійної компетенції для прояву активного громадянства в інформаційному суспільстві на інтернаціоналізованому ринку праці.

У 2015 р. Україна стала асоційованим членом Рамкової програми Європейського Союзу 3 досліджень та інновацій «Горизонт 2020». Дане членство надало українським учасникам рівноправний статус з їхніми європейськими партнерами, а також відкрило можливості впливу на формування змісту програми [7]. Горизонт 2020 - це найбільша програма Європейського Союзу 3 фінансування науки та інновацій з загальним бюджетом близько 80 млрд євро, розрахована на 2014-2020 роки. Програма Горизонт-2020 (Horizon 2020/Н2020) призначена об'єднати фінансування досліджень та інновацій в СС. Ця програма дозволить полегшити виконання науково-дослідних та інноваційних робіт і підвищити їх ефективність, а також стимулюватиме зростання та більшу зайнятість, зважаючи на важливі завдання, які стоять перед усім суспільством.

Слід відзначити, що продовження співпраці з ЄС 3 питань досліджень та інновацій, протидії поширення бідності, використання екологічно чистих технологій, уніфікація освітніх стандартів 3 країнами $Є C$, дозволить Україні в майбутньому розробити та реалізовувати спільні програми, спрямовані на інвестування в інноваційний розвиток людського капіталу.

Висновки. Для сучасного соціально-економічного розвитку країни виконання завдань інноваційного спрямування розвитку людського капіталу $є$ необхідною умовою формування та реалізації національної політики i забезпечення на довгострокову перспективу національної безпеки.

В сучасних умовах важлива функція держави полягає в тому, щоб забезпечити 
взаємоузгодженість адміністративних і економічних важелів 3 використанням усіх можливостей соціальної сфери у розв'язанні проблем розвитку людського капіталу України.

Орієнтація української економіки та будівельної галузі зокрема на формування та розвиток інноваційного людського капіталу має забезпечуватися комплексним заходами, що реалізуються центральними і територіальними органами державної влади, органами управління будівельної галузі, роботодавців і представників сфери освіти та науки, державної служби зайнятості, а також шляхом поглиблення взаємодії з ЄС, в рамках існуючих програм партнерства з європейськими країнами в частині інноваційного розвитку людського капіталу.

\section{Список літератури:}

1. Соціальні індикатори рівня життя населення. Статистичний збірник. - К. Державна служба статистики України, 2018. - 177 с.

2. Грішнова О. Інвестування в людський капітал у системі чинників забезпечення гідної праці / Монографія, 2015. - 222 с.

3. Наукова та інноваційна діяльність України, 2017. Державна служба статистики України. - Київ, 2018. - 178 с.

4. Арабей Е. Новая европейская стратегия «Европа 2020. «Право Европейского Союза». [Електронний ресурс] - Режим доступу: https://eulaw.ru/content/novayaevropejskaya-strategiya-evropa-2020.

5. Europe 2020. [Електронний ресурс] - Режим доступу: https://ec.europa.eu/eu2020/pdf/COMPLET\%20EN\%20BARROSO\%20\%20\%20007\% 20-\%20Europe\%202020\%20-\%20EN\%20version.pdf.

6. Europe 2020 initiatives. [Електронний ресурс] - Режим доступу: https://ec.europa.eu/social/main.jsp?catId=1295\&langId=en .

7. EU cooperation in education and training (ЕT 2020). [Електронний ресурс] Режим доступу: 79https://eur-lex.europa.eu/legal-content/EN/ALL/?uri=celex\%3A 52009 XG0528\%2801\%29

8. Монографія «Людський капітал України: стан, проблеми, перспективи відтворення» / За ред.: В. М. Лича / Київ: КНУБА, 2009. - Ч.1. - 224c.

9. Монографія «Людський капітал України: стан, проблеми, перспективи відтворення» / За ред.: В. М. Лича / Київ: КНУБА, 2009. - Ч.2. - 236с.

10. Лич В.М., Малихіна О.М. Сутнісна характеристика мотиваційного механізму ефективного використання людського капіталу будівельного підприємства //Шляхи підвищення ефективності будівництва в умовах формування ринкових відносин. Зб. наук. праць. Випуск 28, К.: КНУБА, 2012. 268 c. $61-68$ C.

\section{Reference:}

1. Social indicators of living standards of the population. (2018) Statistical collection.

2. Grishnova, O. (2015). Investing in human capital in the system of factors of decent work /Monograph, Kiyv.

3. Scientific and Innovative Activity of Ukraine, 2017. (2018). State Statistics Service of Ukraine.

4. Arabay, E. (2019) New European Strategy "Europe 2020." Law of the European 
Union".[Electronic resource] - URL: https://eulaw.ru/content/novayaevropejskayastrategiya-evropa-2020.

5. 2020. [Electronic resource] - URL: https://ec.europa.eu/eu2020/pdf/COMPLET\%20EN\%20BARROSO $\% 20 \% 20 \% 20007 \%$ 20-\%20Europe\%202020\%20-\%20EN \% 20version.pdf

6. Europe 2020 initiatives. [Online resource] - URL: https://ec.europa.eu/social/main.jsp?catId=1295\&langId=en.

7. EU cooperation in education and training (ET 2020). [Online] - URL: https://eurlex.europa.eu/legal-content/EN/ALL/?uri=celex\%3A52009XG0528\%2801\%29

8. Lych, V.M. (2009). Liudskyi kapital Ukrainy: stan, problemy, perspektyvy vidtvorennia. Monohrafiia (Vol.1).

9. Lych V.M. (2009). Liudskyi kapital Ukrainy: stan, problemy, perspektyvy vidtvorennia Monohrafiia (Vol.2), 236.

10. Lych V.M. \& Malykhina, O.M. (2012). Sutnisna kharakterystyka motyvatsiinoho mekhanizmu efektyvnoho vykorystannia liudskoho kapitalu budivelnoho pidpryiemstva. Shliakhy pidvyshchennia efektyvnosti budivnytstva $v$ umovakh formuvannia rynkovykh vidnosyn, 28, 61-68.

\section{В.В. Шовкивська}

\section{Инновационное развитие человеческого капитала как важный фактор}

Целью статьи является проведение аналитических исследований прочесса инвестирования в инновационное развитие человеческого капитала $и$ зарубежного опыта инвестирования в развитие человеческого капитала.

Определено, что инвестиции в инновационное развитие человеческого капитала в значительной степени зависят от расходов сводного бюджета Украины на сочиильно-культурные мероприятия $и$ образование, которые в последние годы существенно уменьшились (на образование - с 19,1\% в 2014 до 16,8\% в 2018 г. ., на здравоохранение - с 10,9\% в 2014 г2. до 9,3\% в 2018 г.., на сочиильную защиту - на 1,7\%). Недостаточное финансирование со сторонь государства расходов на образование, здравоохранение, духовное и физическое развитие сдерживало в последние годы развитие инновационного человеческого капитала, экономический рост $u$ повышение конкурентоспособности строительной отрасли.

В статье раскрывается влияние инновачионного развития человеческого капитала на экономический рост строчтельной отрасли. Значительное внимание уделено инвестирования в инновационное развитие человеческого капитала Украинь и прогрессивному зарубежного опьта решения данной проблемьл. Отмечается, что ориентация украинской экономики и строительной отрасли в частности на формирование и развитие инновационного человеческого капитала должно обеспечиваться комплексным мероприятиям, которые реализуются центральными и территориальными органами государственной власти, органами управления строительной отрасли, работодателей и представителей сферы образования и науки, государственной службы занятости, а также путем углубления взаимодействия с ЕС в рамках существующих программ партнерства c европейскими странами в части инноващионного развития человеческого капитала.

\section{Ключевые слова: человеческий капитал, строчтельная отрасль,}


инновационное развитие, инвестирование в развитие человеческого капитала.

\section{Shovkivska}

Innovative development of human capital as an important factor of the economic growth of construction industry

In Ukraine, with relatively large amounts of investment in human capital, investment efficiency remains relatively low, so the problem of increasing innovative human capital by improving the efficiency of investing and improving the efficiency of public institutions responsible for its formation and development, which is the basis of economic growth and competitiveness construction industry.

The purpose of the article is to conduct analytical studies of the process of investing in the innovative development of human capital and foreign experience of investing in the development of human capital.

It is determined that investments in innovative development of human capital depend to a large extent on the expenditures of the consolidated budget of Ukraine for sociocultural events and education, which have significantly decreased in recent years (for education - from $19.1 \%$ in 2014 to $16.8 \%$ in 2018). ., for health care - from $10.9 \%$ in 2014 to $9.3 \%$ in 2018, for social protection - by 1.7\%). Insufficient government funding for education, health care, spiritual and physical development has hindered the development of innovative human capital, economic growth and increased competitiveness of the construction industry in recent years.

The article discusses the impact of innovative human capital development on the economic growth of the construction industry. Much attention is paid to investing in the innovative development of human capital of Ukraine and the progressive foreign experience of solving this problem. It is noted that the orientation of the Ukrainian economy and construction industry in particular on the formation and development of innovative human capital should be ensured by comprehensive measures implemented by central and territorial bodies of state power, bodies of management of the construction industry, employers and representatives of education and science, public employment service by deepening engagement with the EU through existing partnership programs with European countries on innovative human capital development.

Key words: human capital, construction industry, innovative development, investing in the development of human capital.

\section{Посилання на статтю}

APA: Shovkivska, V.V. (2019) Innovatsiinyi rozvytok liudskoho kapitalu yak vazhlyvyi chynnyk ekonomichnoho zrostannia budivelnoi haluzi. Shliakhy pidvyshchennia efektyvnosti budivnytstva $v$ umovakh formuvannia rynkovykh vidnosyn, 42, 179-188.

ДСТУ: Шовківська В.В. Інноваційний розвиток людського капіталу як важливий чинник економічного зростання будівельної галузі [Текст] / В.В. Шовківська // Шляхи підвищення ефективності будівництва в умовах формування ринкових відносин. - 2019. - № 42. - С. 179-188. 